\title{
Virtuality as a Motif - A Comparative Study
}

\author{
R. V. $\operatorname{Ram}^{1,2,3,4,5^{*}}$ \\ 'Department of English, SASTRA University, Kumbakonam - 612 001, Tamilnadu, India \\ 2 Professor and Head, Formerly Teacher Trainer, Eritrea Institute of Technology, East Africa \\ ${ }^{3}$ Sanaa University, Yemen \\ ${ }^{4}$ EFLU, Hyderabad, India \\ ${ }^{5}$ RIE, Bangalore, India; ramavram@gmail.com
}

\begin{abstract}
The term "virtual reality" - as originally coined by Antonin Artaud, way back in the 1930s - referred to the effect of the phantasmagorical world of the Theatre wherein characters, objects, and images figure and flit. However, currently Virtual Reality, aka Virtuality, for most of us, is a cyber-age phenomenon, something generated by technology. It is a Computersimulated imaginary world, often displayed on a computer screen, to create a lifelike experience, as for example; videogames, simulated military exercises, therapeutic interventions, virtual classroom, etc. It is, in short, a world as generated by the electronic medium. But if we use a comparative and intertextual perspective, we could see that, besides these two obvious meanings, the term has its deep philosophical connotation too, especially in the postmodern space. 'Reality', for Postmodernists, is allegedly something never accessible to the human mind. It is, to put it in philosophical terms, a 'thingin-itself'. What we have access to, then, is virtuality, in as much as it is generated or contaminated by our linguistic medium. But this determination is often lost on most of us, which is not our fault. We are actually misled by postmodernists who play their 'language games' with us deliberately - if subtly. This article is meant to enable us to develop a comparative/intertextual perspective, which will lead us, as in this case, to a better understanding of the mysterious working of language in literature and life. More specifically, this article will help us to see how a broader comparative perspective can enable us to cope with postmodern writings, creative or otherwise.
\end{abstract}

Keywords: Comparative Criticism, Comparative Philosophy, Difference, Entropy, Etymology, Family Resemblances, Identity, Intentionality, Intertextuality, Language Games, Little Narratives, Maya, Problematizing, Reality, Systems Thinking, Vikalpa, Virtuality (Virtual Reality)

\section{Introduction}

This article is an attempt at comparative criticism, which is basic to the study of Comparative Literature. It seeks, therefore, to throw light on virtuality (or virtual reality), which is a key motif in contemporary literature and as such problematic too. It is apparently, however, unproblematic if it is construed as a motif referring to phenomena as generated by the electronic medium [1]. Actually, it is problematic because it has a deeper, philosophical implication too, especially when we compare its apparent and ontological determinations; that is, when we situate it in an intertextual matrix. This comparative approach will help us to have a better understanding of and insight into working of the motif particularly in postmodern writings, as this comparative study will show. Again, 'Literature' is used here in its etymological sense, as often in the poststructuralist/postmodern writings, to include both creative and critical writings.

\section{Comparative Literature}

A note, at the outset, on Comparative Literature (herein after CL) will make the trajectory of this article clear. It was long ago that, in CL, the paradigm of the 'nationstate' came to be superseded by the paradigm of global

${ }^{*}$ Author for correspondence 
perspective, as in 'World Literature.' Globalization has only accelerated this development. As a result, there is always mounting pressure on Comparativist Methodology to be able to cope with the widening reach and range of the discipline. There is, in other words, a need for more interdisciplinary and more eclectic approaches to Comparative Literature. Otherwise, the discipline would in course of time become moribund, being unable to deal with new literary genres such as postmodern literature, which seek to express increasingly complex human experiences. Gayatri Chakravorty Spivak's Death of a Discipline is a pointer to this. That is indeed why some of the newer subfields of CL are more influenced by contemporary literary theory. The accent now, therefore, is on theoretical acumen and the ability to consider different types of artistic expression concurrently and on linguistic competence of a different kind, as will be borne out by this article.

\section{Methodology}

Methodologically speaking, this article is mainly comparative and intertextual in its approach. Now, I must distinguish between the two terms. Comparison, as we know, includes contrast. A traditional comparativist (or comparatist), that is to say, looks for similarities and differences, which in philosophical terms means looking for identity and difference. Both comparison and intertextuality seem to have more or less the same function, but there is a basic conceptual difference between the two. For comparison, the parallels (analogies) and allusions (cross-references) are there, as author-generated, to compare and comment upon. The intertext, on the other hand, is generated by problematizing the language of the text in question, which often happens in the poststructuralist/ postmodern space. That is to say that intertextuality is a process that generates intertext (s), particularly by opening a given text to problematization. It is basically a reader's perception. Different readers, then, may generate different intertexts, unlike in a traditional comparative study. That is why Julia Kristeva, the originator of this concept, argues that any text is in fact an intertext - the site of an intersection of numberless other texts, and existing only through its relations to other texts [2]. Intertextuality, thus, happens to be one of the latest interventions in CL.

\section{Virtual Reality as a Motif Across Literature}

The term Virtual Reality, as originally coined by the French playwright-actor-director, Antonin Artaud, [3] referred to the effect of the phantasmagorical world of the Theatre wherein characters, objects and images figure and flit. Then it remained in the archives until it was retrieved, given a new meaning and put into circulation by Jaron Lanier, a US computer-artist, in the 1980s [4]. For Lanier it means a Computer-simulated imaginary world, which it is to most of us in this cyber age. Virtual Reality (VR for short) is also known as Virtuality. It is often displayed on a computer screen, to create a lifelike experience, as for example in videogames, movies [e.g., Anaconda and Jurassic Park], simulated military exercises, therapeutic interventions, pedagogic settings as in e-learning, i.e., in virtual classroom, virtual learning, virtual teaching, virtual library, etc. [5] It refers, in short, to a world, as generated by the electronic medium.

But Philip Zhai, a noted contemporary Philosopher (of China), gives it a philosophical twist. He actually assigns Virtual Reality an ontological status. Virtual Reality, according to him, is not just an imaginary world; it is on a par with actual reality [6]. Synonymous with Virtual Reality is the term 'simulacra', introduced way back in ${ }^{2}$ by Jean Baudrillard [7], a French Postmodern philosopher. Baudrillard used it particularly with reference to contemporary media. He too, like Zhai, argues that there is virtually no distinction between reality and simulacra or virtuality!

\section{Problematizing Virtual Reality}

Virtual Reality, besides its obvious meaning, has another determination, especially as used - and never made quite explicit by the users - in the postmodern space. 'Reality', for the Postmodernists, is something allegedly never accessible to the human mind. It is, to put it in philosophical terms, a 'thing-in-itself', comparable to Plato's 'ideas'. We are, in this problematization, guided particularly by three perceptions: philosophical, etymological and analogical (i.e., comparative).

Etymologically, real is derived from 'late Latin' realis, from Latin res 'thing'. What we have access to, then, is 'virtual reality' (or VR for short) inasmuch as 'reality' is - always - mediated by language. That is so because, as it is argued - in effect - notably by Jacques Derrida that whenever we think and whatever we may think of, there is language in it 'always already' $[8,9]$. He cites Geometry as a case in point: Between a geometrical phenomenon as in the geometer's mind and his/her articulation of it, there is the intervention of language $[8,9]$. Comparatively speaking, for Derrida, unmediated consciousness, designated as intentionality in Phenomenology [10], is 
impossible. The notion of virtuality, thus, strikes at the roots of intentionality.

Etymologically, again, the Latin root 'virtus' in Virtuality or Virtual Reality which suggests something perfect [as in 'moral perfection'] or imply something not [so] perfect [something almost like the thing described, in much the same way as 'model' can mean original, as in role model or copy, as in a clay model of the Taj [11]. Virtuality (or virtual reality) is a problematic term, not as simple as is often construed.

\section{6. 'The Real' or 'The Other'}

Problematization of Virtual Reality entails a further probe - into 'the Real' and 'Reality', as used in the postmodern context. We must now turn to Jacques Lacan for help. For, it is he who, of all Postmodernists, is somewhat explicit on the notion of "the Real" [12]. According to him, the Real is the 'unknowable', 'unnamable, 'impossible' and 'traumatic'. It is 'unknowable' in the sense that, as I would argue, it is forbidden knowledge. The Real, Lacan asserts, is that which is outside language and that it resists symbolization absolutely [12]. It is unnamable and that is why it is it. It is "the impossible" because it is impossible to imagine, impossible to integrate into the 'Symbolic' [12]. It is the other, as the biblical story of the Babel seems to suggest. The Babelites ventured to build the City and the Tower. The Tower was supposed to take them to Heaven, to see the Real. But the Other swung into action to thwart this attempt:

\subsection{What the Other Said}

Go to, let us go down, and there Confound their language, that they

May not understand one another's speech

- Genesis 11:7 [13]

\subsection{What the Other Did}

So the Lord scattered them

Abroad from thence upon the face

Of all the earth: and they left off

To build the city.

Therefore the name of it

Called Babel; because the Lord did

There confound the language of all

The Earth: and from thence did the

Lord scatter them abroad upon

The face of all the earth". [13]
The other, as such, is inaccessible, absent, unnamable and 'ex-centric' (in a cosmological sense). That is a bitter lesson for the Babelite community, which it had to learn long, long ago - paying an incalculably heavy price. All is this virtual history. However, the trauma seems to persist in human minds, especially in the minds of those of the postmodern persuasion. And it is for this reason and in that sense - presumably - that Lacan calls it 'traumatic'. What we actually have access to, then, is virtually reality, a simulacrum, if you like, and as such it is analogous to the Hindu concept of maya or the Buddhist notion of vikalpa (illusion). But the difference between $V R$ and the Indian notions is probably this: $V R$ is said to be the only reality available to Human, whereas the Indian analogue, màya or vikalpa, is said to be the result of an 'unenlightened' perspective and is as such regarded as illusion, which ought to be dispelled through human endeavour [11].

But, incidentally, a question may arise in the comparative space, which must be answered. Otherwise, the readers across the globe may develop cognitive dissonance. The question is: Is it possible to dispel such illusions? The answer is: "Yes and no". For, it depends. One would necessarily be a participant-observer in the event and as such influences the result. To put in familiar register, in the manner of Henry Ford, "Whether you think that you can (break down this illusion) or cannot, you are right!" Postmodernists, however, think that we cannot.

\section{The Language Game}

Here, again, we shall be guided by philosophy and analogy. Practically, it involves a study of both the differences among different Postmodernists (as brought to light by their family quarrels) and the similarities or 'family resemblances,' to borrow a term from Wittgenstein [14]. In this kind of study, one should not be misled because of the language game played by Lyotard. We would do well to remember that virtual reality, as the problematic indicates at the outset, could mean reality as generated by the medium (of language). Otherwise, we are very likely to be misled about $V R$ by its obvious meaning - because of the Lyotardian camouflage or language game, which he and writers of his persuasion cleverly play with us all, that is, with the rest of the world! If we did not learn to cope with such 'language games,' we would unwittingly generate vertiginous 'micro-narratives', which is what happens very often. And it would be difficult to read any postmodern text, creative or otherwise, more difficult to translate one. 


\section{8. 'Language Games'}

It is imperative to explain 'Language-games' here at this point. It was, as we all know, originally used by Wittgenstein [14], as noted earlier. According to him, a language game consists of language and the actions into which it is woven. Language games, he significantly added, are connected by family resemblance. The concept was intended "to bring into prominence the fact that the speaking of language is part of an activity, or a form of life" [14]. This concept was appropriated by Lyotard [15] and used in a slightly different sense and with a different emphasis. It denotes, for Lyotard, the multiplicity of communities of meaning, the innumerable and incommensurable separate systems or micro-narratives or little narratives (as for example little interventions/discourses of identity politics), in which meanings are produced and rules for their circulation are created, as opposed to metanarratives (like for example, Capitalism or Marxism or Socialism) [15].

\section{The Critical Difference}

But whereas Wittgenstein emphasizes 'family resemblance' [14] (that is to say, identity), as noted earlier, Lyotard emphasizes multiplicity [15] (i.e., difference). Lyotard urges us to become alert to this difference, diversity, the incompatibility of our aspirations, beliefs and desires, and for that reason postmodernity is characterized by an abundance of 'micronarratives' (or little narratives). Again, while Wittgenstein's tone is clinical and expository, Lyotard's sounds apocalyptic, especially with reference to multiplicity of narratives, which is comparable to the rise in 'entropy' (i.e., randomness). And we must note that the concept 'Postmodern' for Lyotard is not simply a periodic notion, as is often misconstrued. Postmodern, for Lyotard, is yet to come! He probably bases his claim on the etymology of 'Post-', which - interestingly enough - means in its original Latinate sense both 'after' and 'behind' [15].

\section{Identity vis-a-vis Difference}

Again, while Lyotard sounds helpful in urging us to be alert to difference, he is also positively misleading. For, if we take him seriously and look at difference, we will pass over identity, that is, the similarities (family resemblance). We will, then, find ourselves in a maze of language games, as it were. Instead, if we look at both 'difference' and 'identity', we can see through the postmodernists' language games. The postmodernists' intention is probably to replicate, as does a computer virus, the Babel scene/game, where - as noted earlier - the Babelites could not understand each other's speech. Now, the postmodernists intend thereby to turn virtual history into 'virtual' reality.

But have the postmodernists succeeded in their attempt to confound readers? Yes, virtually so! The evidence, already cited, is the confusion in the minds of most readers about the very term postmodernism: Is it a period and if so is it something still on, over or yet to come? One more is Noam Chomsky's plight. The great linguist, author of Transformational-Generative Grammar, unable to understand the language games, cries in despair: "No one seems to explain to me why the latest post-this-and-that is (for the most part) other than truism, error, or gibberish and I don't know how to proceed" [16].

\section{Family Resemblances}

Now to the examples of Poststructuralist-Postmodernist family resemblance: Lyotard's 'language games' are comparable to Derrida's 'play' (of signifiers) and Foucauldian 'discourse' (where 'dis-' is a negative prefix). Again, Lyotard's emphasis on 'incommensurability' of language games can be interpreted as follows: Apparently, language games seek to 'deconstruct' one another! They all, Poststructuralists and postmodernists, seem to quarrel with each other: An interesting example is Derrida's quarrel with Lacan, which will not be discussed here, as it is beyond the scope of this article. But in spite of their family quarrels, these Postmodernists have their strong affinities and family resemblances too, as illustrated above, which have helped us to see the interrelatedness of their concepts and also see through their language games, as for instance virtuality (virtual reality). The term language games', is used in this article sometimes in the postmodern sense and sometimes in the obvious sense, as for instance in the previous sentence. It is all part of the game!

\section{Conclusion}

Now, in conclusion, I would like to highlight four points. But, before I conclude, I must admit that this article, originally meant to be comparative, turned out to be virtually prescriptive, especially towards the end, which may be attributed to an occupational hazard - of about four decades of mentoring!

One: The motif of Virtuality may be taken, as the article demonstrates, in three different senses, literary (theatrical, fictional, etc.), technological and philosophical. For, from a relativistic angle, whatever one believes to be true in a given moment must be virtually true. Comparatively speaking, 
then, a scene from a play or film, a page from a novel, our own countless dreams, and fears - all the phantasmagoria may be regarded as virtual reality, in the same way as a ghost story can be virtual reality to a child.

Come to think of it, paradigm shifts in science also point to the fact that earlier paradigms were Virtual Realities after all, as in the following cases: Geocentricism versus Heliocentrism, Classical Physics versus Quantum Mechanics, Behaviourism versus Cognitivism, etc., etc. Most of our own beliefs, political, religious or whatever, are after all instances of virtuality. So, we are all part of virtuality, living in it and in the process and in our own ways constructing our own virtual realities. We will, however, do well to look for and be alert not only to difference but to identity as well, taking the cue both from Wittgenstein and Lyotard. Otherwise, life would be full of terrible things that never happened or would never happen!

Two: The article also emphasizes the need to exercise a different kind of linguistic competence - of problematizing a text, especially by reading it both synchronically and diachronically (i.e. by taking etymology into account) as necessary.

Three: Again, this article points to the need for comparativists to broaden the scope of CL. This we can do by undertaking intertextual as well as analogical study - not only of texts but also of systems, say, of philosophy, belief, history, culture, etc., as the case may be. The latter is otherwise known as Systems Thinking. Intertextuality ought to be regarded as one of the latest avatars of Comparative Literature.

Four: This approach will also save comparativist-translators from the pitfalls of mistranslation or distortion, especially when dea ling with postmodern texts.

\section{Works Cited}

1. Krishnaswamy N., et al. "Contemporary Literary Theory". Delhi: Macmillan, 2001, ISBN 0333 937120. [Print].

2. Abrams M. H., "A Glossary of Literary Terms". $7^{\text {th }}$ ed. 2003, pp. 317, Baudrillard J., 1994, Simulacra and Simulation, Trans Sheila Glaser, Michigan: University of Michigan Press, 1981.
3. Artaud A., "The theatre and its double". 1938, Available: http://www.p2c2e.de/cyberhobbit/diss/diss08.html

4. Lanier J., "The theatre and its double”. 1980, Available: http:// www.p2c2e.de/cyberhobbit/diss/diss08.html

5. Ram R. V., "E-learning and E-mancipatory English - a perspective”. Reflections on English Language Teaching, Goel S., Ed., Ladnun: JVB Institute, 2012, [Print].

6. Zhai P., "Get real: a philosophical adventure in virtual reality". Rowman and Littlefield, 1998.

7. Baudillard J., "Simulacra and Simulation". Sheila G., Ed., Michigan University: University of Michigan Press, 1981.

8. Derrida J., "Edmund Husserl's Origin of Geometry: an introduction". 1962.

9 Derrida J., "Speech and phenomena and other Essays on Husserl's Theory of Signs". Allison D. B., Ed., Evanston: Northwestern University Press, 1973.

10. Sartre J.-P., "Being and Nothingness". London: Simon and Schuster (UK), 1943.

11. Krishnaswamy N., et al., "India's language philosophy with a focus on comparative study”. Delhi: Pearson, 2013, pp. 34. [Print].

12. Lacan J., "The Seminar of Jacques Lacan: Book XI: The Four Fundamental Concepts of Psychoanalysis”. Miller J.-A., Ed., Cambridge: CUP Archive, 1988.

13. Genesis 11:7, Bible, 2014 Dec 12. Available: http://www.icr. org/bible/Genesis/11:1-9.

14. Wittgenstein L., "Philosophical Investigations". Malden: Blackwell, 1953.

15. Lyotard J. F., “The postmodern condition: a report on knowledge”. Bennington G. and Massumi B., Ed., Minneapolis: University of Minnesota Press, 1984. [La Condition postmoderne: Rapport sur le savoir. Paris: Editions de Minuit, 1979].

16. Choamsky N. "Rationality/Science". Z Papers, 1995, Special Issue. Available: http://www.chomsky.info/articles.html

\section{Other References}

1. Available: http://www.costis.org/x/lyotard/schultz.html

2. Available: http://www.sociology.org.uk/ws1sw2.html

3. Available: http://en.wikipedia.org/wiki/Language-game

4. Available: http://en.wikipedia.org/wiki/Simulacra_and_ Simulation

5. Available: http://en.wikipedia.org/wiki/Māya (illusion) 